\title{
The scope of complementary and alternative medicine in Poland
}

\author{
Adrian Perdyan ${ }^{1}$, Magdalena Wasiukiewicz², Piotr Szastok², Jacek Jassem³ \\ IInternational Research Agenda 3P Medicine Laboratory, Medical University of Gdansk, Gdansk, Poland \\ ${ }^{2}$ Student Scientific Circle of Oncology \& Radiotherapy, Medical University of Gdansk, Gdansk, Poland \\ ${ }^{3}$ Department of Oncology \& Radiotherapy, Medical University of Gdansk, Gdansk, Poland
}

Introduction. Complementary and alternative medicine (CAM) is widely used by patients. The most frequent CAM users are patients with cancer, but patients with other chronic diseases also utilize these methods.

Materials and methods. Data on the use of CAM were obtained from Google searches. For each specific search term, the first three Google pages were analyzed.

Results. The analysis included 91 CAM institutions matching the inclusion criteria. The most common anticancer services were intravenous vitamin C infusion, saltwater, intravenous infusion of glutathione, colon irrigation, an anticancer diet, bio-resonance, and intravenous ozone infusions. The most common non-cancer entities treated were rheumatic diseases, chronic fatigue syndrome, arterial hypertension, allergies, borreliosis, diabetes, atherosclerosis, and depression. Anticancer therapies were more expensive than those used for non-malignant diseases (medians 250 PLN and 170 PLN, respectively; $p=0.041$ ).

Conclusions. This study provides a comprehensive overview of CAM methods used in Poland. These data may facilitate social education and the development of preventive measures.

Key words: complementary medicine, alternative medicine, cancer, chronic diseases

\section{Introduction}

Complementary and alternative medicine (CAM) includes complementary medicine, which claims to reinforce standard medical treatments, and alternative medicine, which refers to methods intended to replace standard medical treatments. CAM methods are widely used all over the world [1]. The most frequent CAM users are cancer patients, but patients with other chronic diseases (e.g., type 2 diabetes, arterial hypertension, depression, obesity, chronic pain, and allergies) also practice these methods [2-6]. Despite its potential harmful effects and the lack of evidence-based benefits, the usage of CAM has significantly increased in recent years [7]. In Western countries, up to 40-90\% of cancer patients admit to using CAM methods, and consistent growth has also been observed among patients with other chronic diseases [8]. Recent reports show that more than 70\% of United States inhabitants have used CAM at least once in their lives [9]. In 2007, the total annual expenditure on CAM services in the United States was 34 billion USD - a 25\% increase compared to 1997 [10]. In 2016, the reported yearly out-of-pocket spending on CAM services in the United States reached 58.5 billion USD $[11,12]$.

\section{How to cite:}

Perdyan A, Wasiukiewicz M, Szastok P, Jassem J. The scope of complementary and alternative medicine in Poland. NOWOTWORY J Oncol 2021 ; 71: 357-372.

This article is available in open access under Creative Common Attribution-Non-Commercial-No Derivatives 4.0 International (CC BY-NC-ND 4.0) license, allowing to download articles and share them with others as long as they credit the authors and the publisher, but without permission to change them in any way or use them commercially. 
Meta-analyses and systematic reviews assessing the efficacy of CAM provide conflicting results [13]. Due to their low-quality methodology, most CAM studies do not allow for meaningful conclusions [14]. CAM phase III clinical trials are less likely than non-CAM clinical trials to report disease-related outcomes, be supported by pre-trial results, and meet their endpoints [15]. Notably, the anticancer treatment mechanisms of CAM methods are often attributed to a single, specific pathophysiological effect rather than multiple regulatory pathways or influences on different effectors. CAM compounds may also have several active components whose effects may be cell-determined or epigenetically determined. Consequently, CAM methods are largely scientifically unproven. Even though some preclinical studies and preliminary clinical studies have postulated anticancer effects, the clinical relevance of these findings is highly questionable [16].

Data on types of CAM methods and their applications are scarce. The purpose of this study was to assess the scope of CAM practices offered to patients in Poland, with a particular focus on anticancer therapies.

\section{Material and methods}

In August 2020, we performed an Internet search using the Google Search web facility. The first three pages of search results were analyzed for each of the following search terms: "cancer treatment", "alternative medicine", "complementary medicine", "intravenous vitamin infusions in cancer treatment", "vitamin C in cancer treatment","bioresonance therapy in cancer treatment", "whole-body hyperthermia in cancer treatment", "hyperthermia in cancer treatment", "saltwater in cancer treatment" and "colon irrigation in cancer treatment." Method specific search queries were selected based on their frequent use in CAM institutions found by general search terms. We only included articles that provided an institution with contact information given on its website, a list of methods used, and indications for their use.

All institutions were categorized as follows, according to the CAM methods used:

- anticancer therapies,

- supportive cancer therapies,

- anticancer and supportive cancer therapies,

- therapies for non-malignant diseases.

This subdivision into categories was performed independently by three individuals (AP, PS, and MW), and the final group assignment was based on their collective opinion. Additionally, all services were divided into those using drug substances (any substances that were ingested or injected into the body) or those using other methods. The following data were abstracted from website pages and included in the Excel database: name of the institution, city, type of institution, voivodeship, city population, contact information, website page, diseases treated, methods used, methods used for the treatment of cancer and other diseases, number of physicians employed and their me- dical specializations, type of service, service fees, and reference to E-published literature. Institutions without information about fees of CAM services available on the website $(n=30)$ were contacted by phone. For institutions that provided ranges of fees for consultations and procedures, the mean values were calculated. Institutions that set their consultation and procedure fees individually were not included in the analysis. A non-parametric (Mann-Whitney U) test for independent variables was used to compare treatment and consultation fees.

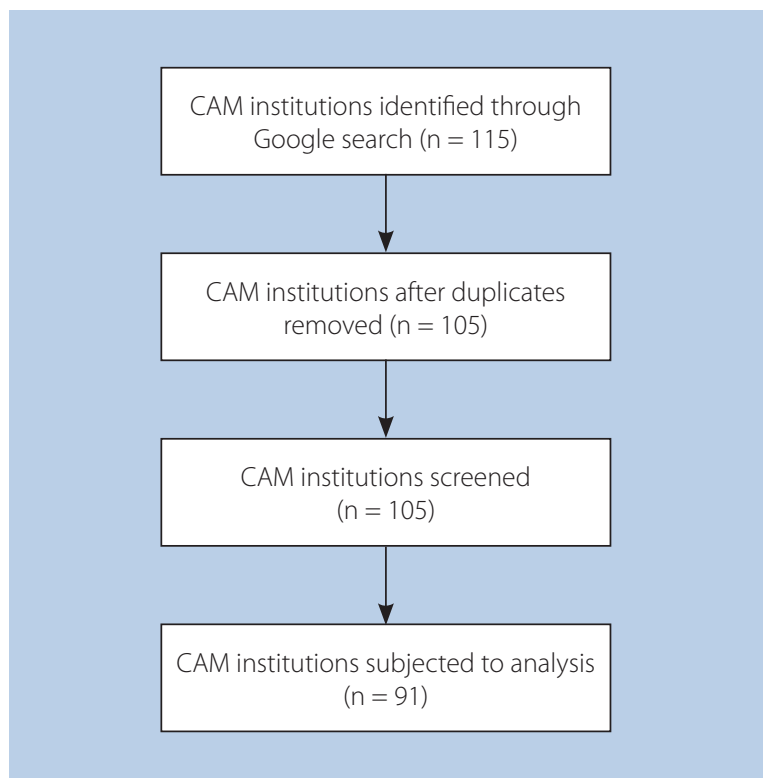

Figure 1. Flow chart of the inclusion of CAM institutions

Table I. Clinical entities treated in all CAM institutions $(n=91)$

\begin{tabular}{|lll|}
\hline Disease & n & $\%$ \\
\hline cancer & 52 & $57 \%$ \\
\hline anticancer therapy & 37 & $41 \%$ \\
\hline supportive cancer therapy & 42 & $46 \%$ \\
\hline rheumatic diseases & 53 & $58 \%$ \\
\hline chronic fatigue syndrome & 51 & $56 \%$ \\
\hline arterial hypertension & 45 & $50 \%$ \\
\hline allergies & 45 & $49 \%$ \\
\hline borreliosis & 44 & $48 \%$ \\
\hline atherosclerosis & 43 & $47 \%$ \\
\hline diabetes & 43 & $47 \%$ \\
\hline depression & 42 & $46 \%$ \\
\hline chronic infections & 36 & $46 \%$ \\
\hline migraine & 37 & $41 \%$ \\
\hline pain from various origins & 39 & $40 \%$ \\
\hline obesity & 40 & $43 \%$ \\
\hline hepatic diseases & 39 & $43 \%$ \\
\hline atopic dermatitis, psoriasis & $39 \%$ \\
\hline
\end{tabular}


Table I. cont. Clinical entities treated in all CAM institutions $(n=91)$

\begin{tabular}{|c|c|c|}
\hline Disease & $\mathbf{n}$ & $\%$ \\
\hline asthma & 35 & $39 \%$ \\
\hline addictions & 33 & $36 \%$ \\
\hline immunity deficiency & 31 & $34 \%$ \\
\hline acne & 31 & $34 \%$ \\
\hline ulcerative colitis, Crohn disease & 31 & $34 \%$ \\
\hline candidiasis & 30 & $33 \%$ \\
\hline heavy metals or mushroom intoxication & 30 & $33 \%$ \\
\hline neurological disorders & 29 & $32 \%$ \\
\hline oxidative stress & 29 & $32 \%$ \\
\hline parasitic diseases & 26 & $29 \%$ \\
\hline hangover & 25 & $28 \%$ \\
\hline coronary artery disease & 23 & $25 \%$ \\
\hline multiple sclerosis & 22 & $24 \%$ \\
\hline autoimmune diseases & 22 & $24 \%$ \\
\hline bedsores, burns, ulcers & 22 & $24 \%$ \\
\hline ischemic stroke & 21 & $23 \%$ \\
\hline impotence & 20 & $22 \%$ \\
\hline cardiovascular diseases & 19 & $21 \%$ \\
\hline irritable bowel syndrome & 19 & $21 \%$ \\
\hline heart diseases & 18 & $20 \%$ \\
\hline gastric and duodenal ulcers & 18 & $20 \%$ \\
\hline Alzheimer's disease & 16 & $18 \%$ \\
\hline myocardial infarction & 16 & $18 \%$ \\
\hline pneumonia, bronchitis & 15 & $17 \%$ \\
\hline thyroid diseases & 14 & $15 \%$ \\
\hline $\begin{array}{l}\text { chronic inflammation of the urethra and } \\
\text { prostate }\end{array}$ & 14 & $15 \%$ \\
\hline intermittent claudication & 13 & $14 \%$ \\
\hline gout & 13 & $14 \%$ \\
\hline Parkinson's disease & 13 & $14 \%$ \\
\hline osteoporosis & 12 & $13 \%$ \\
\hline Hashimoto's disease & 12 & $13 \%$ \\
\hline sciatica & 12 & $13 \%$ \\
\hline chronic gastritis & 11 & $12 \%$ \\
\hline eye diseases & 11 & $12 \%$ \\
\hline pancreatic function disorders & 11 & $12 \%$ \\
\hline fibromyalgia & 10 & $11 \%$ \\
\hline thromboembolism & 10 & $11 \%$ \\
\hline autism & 9 & $10 \%$ \\
\hline endocrine disorders & 9 & $10 \%$ \\
\hline kidney diseases & 9 & $10 \%$ \\
\hline digestive system diseases & 9 & $10 \%$ \\
\hline herpes & 8 & $8.8 \%$ \\
\hline anemia & 8 & $8.8 \%$ \\
\hline
\end{tabular}

\begin{tabular}{|c|c|c|}
\hline Disease & $n$ & $\%$ \\
\hline tinnitus & 8 & $8.8 \%$ \\
\hline varicose veins & 8 & $8.8 \%$ \\
\hline food intolerances & 7 & $7.7 \%$ \\
\hline cataract & 7 & $7.7 \%$ \\
\hline viral hepatitis & 7 & $7.7 \%$ \\
\hline paralysis & 6 & $6.6 \%$ \\
\hline heart arrhythmia & 6 & $6.6 \%$ \\
\hline hemorrhoids & 6 & $6.6 \%$ \\
\hline colon dysfunction & 6 & $6.6 \%$ \\
\hline respiratory system diseases & 6 & $6.6 \%$ \\
\hline other & 5 & $5.5 \%$ \\
\hline deafness, hearing loss & 5 & $5.5 \%$ \\
\hline infertility & 5 & $5.5 \%$ \\
\hline $\begin{array}{l}\text { inflammation of women reproductive } \\
\text { organs }\end{array}$ & 5 & $5.5 \%$ \\
\hline chickenpox & 4 & $4.4 \%$ \\
\hline sterility & 4 & $4.4 \%$ \\
\hline $\begin{array}{l}\text { human immunodeficiency virus infection/ } \\
\text { acquired immune deficiency HIV/AIDS }\end{array}$ & 4 & $4.4 \%$ \\
\hline cerebral palsy & 4 & $4.4 \%$ \\
\hline chronic diseases & 4 & $4.4 \%$ \\
\hline neuropathies & 3 & $3.3 \%$ \\
\hline bedwetting & 3 & $3.3 \%$ \\
\hline bile ducts and gall bladder inflammation & 3 & $3.3 \%$ \\
\hline posture defects & 2 & $2.2 \%$ \\
\hline heart defects & 2 & $2.2 \%$ \\
\hline endometriosis & 2 & $2.2 \%$ \\
\hline cellulite, stretch marks, scars & 2 & $2.2 \%$ \\
\hline neuritis & 2 & $2.2 \%$ \\
\hline schizophrenia & 2 & $2.2 \%$ \\
\hline viral diseases & 2 & $2.2 \%$ \\
\hline sepsis & 2 & $2.2 \%$ \\
\hline chronic obstructive pulmonary disease & 2 & $2.2 \%$ \\
\hline attention deficit hyperactivity disorder & 2 & $2.2 \%$ \\
\hline $\begin{array}{l}\text { acute and chronic inflammation of } \\
\text { reproductive organs }\end{array}$ & 2 & $2.2 \%$ \\
\hline all diseases (bioresonance therapy) & 2 & $2.2 \%$ \\
\hline stupor & 1 & $1.1 \%$ \\
\hline anorexia & 1 & $1.1 \%$ \\
\hline bulimia & 1 & $1.1 \%$ \\
\hline blindness & 1 & $1.1 \%$ \\
\hline infectious myocarditis & 1 & $1.1 \%$ \\
\hline tooth decay & 1 & $1.1 \%$ \\
\hline hair loss & 1 & $1.1 \%$ \\
\hline seasickness & 1 & $1.1 \%$ \\
\hline
\end{tabular}


Table I. cont. Clinical entities treated in all CAM institutions $(n=91)$

\begin{tabular}{|lcc|}
\hline Disease & n & $\%$ \\
\hline tetanus & 1 & $1.1 \%$ \\
\hline retinopathy & 1 & $1.1 \%$ \\
\hline acidosis & 1 & $1.1 \%$ \\
\hline post-infection paralysis & 1 & $1.1 \%$ \\
\hline absorption disorders & 1 & $1.1 \%$ \\
\hline Huntington's disease & 1 & $1.1 \%$ \\
\hline
\end{tabular}

\section{Results}

The screening identified a total of 115 institutions providing CAM services, 91 of which met the study's inclusion criteria and were further analyzed (fig. 1). 91\% of CAM institutions were located in cities inhabited by over 100,000 people. Of the 109 entities treated, the most common were rheumatic

Table II. Practices used across all CAM institutions $(n=91)$

\begin{tabular}{|c|c|c|}
\hline Method & n & $\%$ \\
\hline vitamin C intravenous infusion & 47 & $52 \%$ \\
\hline bioresonance & 44 & $48 \%$ \\
\hline vitamin intravenous infusion (other than vitamin C) & 42 & $46 \%$ \\
\hline ozone therapy - autotransfusion & 32 & $35 \%$ \\
\hline intravenous infusion of alpha-lipoic acid & 24 & $26 \%$ \\
\hline diet & 19 & $21 \%$ \\
\hline colon irrigation & 19 & $21 \%$ \\
\hline herbal medicine & 13 & $14 \%$ \\
\hline intravenous infusion of glutathione & 13 & $14 \%$ \\
\hline acupuncture & 10 & $11 \%$ \\
\hline massage & 10 & $11 \%$ \\
\hline ear candling & 10 & $11 \%$ \\
\hline chelation & 9 & $10 \%$ \\
\hline hyperthermia & 7 & $7.7 \%$ \\
\hline oxygen therapy & 6 & $6.6 \%$ \\
\hline medicinal leeches & 6 & $6.6 \%$ \\
\hline homeopathy & 5 & $5.5 \%$ \\
\hline iridology & 5 & $5.5 \%$ \\
\hline reflexology & 5 & $5.5 \%$ \\
\hline laser therapy & 5 & $5.5 \%$ \\
\hline energy medicine, chakra therapy & 5 & $5.5 \%$ \\
\hline quantum therapy & 4 & $4.4 \%$ \\
\hline ion detox - feet soaking in saltwater & 4 & $4.4 \%$ \\
\hline electrotherapy & 4 & $4.4 \%$ \\
\hline bubbles & 3 & $3.3 \%$ \\
\hline magnetotherapy & 3 & $3.3 \%$ \\
\hline hyperbaric chamber & 3 & $3.3 \%$ \\
\hline plasmotherapy - Rife's generator & 3 & $3.3 \%$ \\
\hline hypnosis & 2 & $2.2 \%$ \\
\hline psychotherapy & 2 & $2.2 \%$ \\
\hline reiki & 2 & $2.2 \%$ \\
\hline
\end{tabular}

\begin{tabular}{|lll|}
\hline Disease & $\mathbf{n}$ & $\%$ \\
\hline age-related macular degeneration & 1 & $1.1 \%$ \\
\hline hypercholesterolemia & 1 & $1.1 \%$ \\
\hline polycystic ovary syndrome & 1 & $1.1 \%$ \\
\hline Down's syndrome & 1 & $1.1 \%$ \\
\hline shingles & 1 & $1.1 \%$ \\
\hline fungal sepsis & 1 & $1.1 \%$ \\
\hline
\end{tabular}

diseases (58\%), cancer (57\%), chronic fatigue syndrome (56\%), arterial hypertension (50\%), allergies (49\%), borreliosis (48\%), type 2 diabetes (47\%), atherosclerosis (47\%), depression (46\%), and chronic infections (46\%) - table I. There were 61 and 73 institutions offering drug- and non-drug-based methods, respectively. A total of 70 methods were offered (18 drug-

\begin{tabular}{|c|c|c|}
\hline Method & $n$ & $\%$ \\
\hline moxibustion & 2 & $2.2 \%$ \\
\hline electromagnetic waves & 2 & $2.2 \%$ \\
\hline naturopathy & 2 & $2.2 \%$ \\
\hline matrix regenerating therapy & 2 & $2.2 \%$ \\
\hline coenzyme Q10 intravenous infusion & 2 & $2.2 \%$ \\
\hline essential oils & 1 & $1.1 \%$ \\
\hline physical therapy & 1 & $1.1 \%$ \\
\hline ganotherapy & 1 & $1.1 \%$ \\
\hline cryotherapy & 1 & $1.1 \%$ \\
\hline aromatherapy & 1 & $1.1 \%$ \\
\hline clairvoyance & 1 & $1.1 \%$ \\
\hline su jok & 1 & $1.1 \%$ \\
\hline collagen water & 1 & $1.1 \%$ \\
\hline choline intravenous infusion & 1 & $1.1 \%$ \\
\hline curcumin & 1 & $1.1 \%$ \\
\hline immunotherapy (thymostimulinum) & 1 & $1.1 \%$ \\
\hline dimethyl sulfoxide & 1 & $1.1 \%$ \\
\hline peptide therapy & 1 & $1.1 \%$ \\
\hline artesunate & 1 & $1.1 \%$ \\
\hline oligonucleotide therapy & 1 & $1.1 \%$ \\
\hline dowsing & 1 & $1.1 \%$ \\
\hline acupressure & 1 & $1.1 \%$ \\
\hline taping & 1 & $1.1 \%$ \\
\hline bipolar bioresonance therapy & 1 & $1.1 \%$ \\
\hline revolutionary scanning regulatory thermography & 1 & $1.1 \%$ \\
\hline viofor magnetic field therapy & 1 & $1.1 \%$ \\
\hline kangen water & 1 & $1.1 \%$ \\
\hline aloes and propolis & 1 & $1.1 \%$ \\
\hline mistletoe & 1 & $1.1 \%$ \\
\hline vibroacoustic therapy & 1 & $1.1 \%$ \\
\hline hippotherapy (horse therapy) & 1 & $1.1 \%$ \\
\hline
\end{tabular}


Table II. cont. Practices used across all CAM institutions ( $\mathrm{n}=91)$

\begin{tabular}{|lcc|}
\hline Method & n & $\%$ \\
\hline Zenni's electrostimulation & 1 & $1.1 \%$ \\
\hline geopathic test & 1 & $1.1 \%$ \\
\hline Bach's therapy & 1 & $1.1 \%$ \\
\hline Schumann's platform & 1 & $1.1 \%$
\end{tabular}

and 52 non-drug-based), the most common of which were intravenous vitamin C infusion (IVCl; 11.5\%) and bioresonance (10.7\%) - table II; supplementary tables I-XI. The mean number of methods used per individual CAM institution was 4.6 (range: 1-15), and the mean number of diseases or groups of diseases treated per individual CAM institution was 18.5 (range: 1-51). $41 \%$ of institutions offered anticancer treatment; $46 \%$ offered supportive cancer treatment; $32 \%$ offered anticancer and cancer-supportive treatment; and $42 \%$ offered non-cancer treatment. Drug-based and non-drug-based methods to treat cancer were used by $73 \%$ and $78 \%(p=0.52)$ of institutions, respectively. Anticancer therapy was used by $72 \%$ of institutions offering drug-based methods and $64 \%$ of institutions offering non-drug-based methods ( $p=0.33$ ). Oxidative stress and hangover after alcohol use were more frequently treated with drug-based methods than with non-drug-based methods

\begin{tabular}{|lcc|}
\hline Method & n & $\%$ \\
\hline bioelectronics - beta examination & 1 & $1.1 \%$ \\
\hline fotostimulation & 1 & $1.1 \%$ \\
\hline biofeedback & 1 & $1.1 \%$ \\
\hline gemmotherapy & 1 & $1.1 \%$ \\
\hline
\end{tabular}

(46\% vs. 26\%; $p=0.02$ and 41\% vs. 15\%; $p<0.01$, respectively), whereas the opposite was true for addiction (23\% vs. 43\%; $p=0.02$ ), sciatica (3.3\% vs. 16\%; $p=0.01$ ), allergies (38\% vs. $59 \% ; p=0.01$ ), and parasitic diseases (18\% vs. 36\%; $p=0.02$ ) - supplementary table XII. The number of anticancer or supportive cancer therapies provided by particular institutions varied between 1 and 13, with 48\% of institutions providing only 1 method (tab. III). The most common anticancer therapy was IVCI (19\%), followed by intravenous infusion of glutathione and intravenous infusions of ozone (6.0\% each), colon irrigation and an anticancer diet (5.3\% each), and bioresonance therapy (4.6\%) - table IV. Only 35\% of institutions reported the names (93 total) and specialties (36 total) of their employed physicians. There were no significant differences between cancer- and non-cancer-treating institutions regarding the employment of physicians (37\% vs. $25 \%$, $p=0.27$ ) or the frequency of drug-

Table III. Number of cancer services offered by CAM institutions

\begin{tabular}{|lccc|}
\hline $\begin{array}{l}\text { Number of cancer } \\
\text { services }\end{array}$ & $\begin{array}{c}\text { Number of } \\
\text { institutions }\end{array}$ & All institutions $(\mathbf{n = 9 1 )}$ & Institutions providing cancer services $(\mathbf{n}=\mathbf{5 2})$ \\
\hline 1 & 25 & $28 \%$ & $48 \%$ \\
\hline 2 & 6 & $6.6 \%$ & $12 \%$ \\
\hline 3 & 6 & $6.6 \%$ & $12 \%$ \\
\hline 4 & 1 & $1.1 \%$ & $1.9 \%$ \\
\hline 5 & 6 & $6.6 \%$ & $12 \%$ \\
\hline 6 & 3 & $3.3 \%$ & $5.8 \%$ \\
\hline 7 & 3 & $3.3 \%$ & $5.8 \%$ \\
\hline 9 & 1 & $1.1 \%$ & $1.9 \%$ \\
\hline 13 & 1 & $1.1 \%$ & $1.9 \%$ \\
\hline
\end{tabular}

Table IV. Services offered by CAM institutions for cancer patients

\begin{tabular}{|lccc|}
\hline Service & $\mathrm{n}=52$ & $\%$ & $\begin{array}{c}\text { Median } \\
\text { fee per } \\
\text { procedure } \\
\text { (PLN)* }\end{array}$ \\
\hline vitamin C intravenous infusion & 28 & $19 \%$ & 225 \\
\hline $\begin{array}{l}\text { ozone therapy - } \\
\text { autohemotransfusion }\end{array}$ & 9 & $6.0 \%$ & 173 \\
\hline infusion intravenous glutathione & 9 & $6.0 \%$ & 190 \\
\hline colon irrigation & 8 & $5.3 \%$ & 180 \\
\hline diet & 8 & $5.3 \%$ & - \\
\hline bioresonance & 7 & $4.6 \%$ & 243 \\
\hline ozone salt intravenous infusion & 7 & $4.6 \%$ & 175 \\
\hline whole-body hyperthermia & 6 & $4.0 \%$ & 1450 \\
\hline
\end{tabular}

\begin{tabular}{|lccc|}
\hline Service & $\mathrm{n}=52$ & $\%$ & $\begin{array}{c}\text { Median } \\
\text { fee per } \\
\text { procedure } \\
\text { (PLN)* }\end{array}$ \\
\hline $\begin{array}{l}\text { alpha-lipoic acid intravenous } \\
\text { infusion }\end{array}$ & 6 & $4.0 \%$ & 188 \\
\hline $\begin{array}{l}\text { local hyperthermia } \\
\text { superficial ozone therapy }\end{array}$ & 5 & $3.3 \%$ & 550 \\
\hline $\begin{array}{l}\text { hyperbaric chamber } \\
\text { vitamin B complex intravenous }\end{array}$ & 5 & $3.3 \%$ & 150 \\
\hline infusion & 3 & $2.0 \%$ & 170 \\
\hline bioenergotherapy & 3 & $2.0 \%$ & 235 \\
\hline aromatherapy & 2 & $1.3 \%$ & - \\
\hline & & & - \\
\hline
\end{tabular}


Table IV. cont. Services offered by CAM institutions for cancer patients

\begin{tabular}{|l|ccc|}
\hline Service & n 52 & $\%$ & $\begin{array}{c}\text { Median } \\
\text { fee per } \\
\text { procedure } \\
\text { (PLN)* }\end{array}$ \\
\hline cryotherapy & 2 & $1.3 \%$ & - \\
\hline folic acid intravenous infusion & 2 & $1.3 \%$ & - \\
\hline ozone inhalation & 2 & $1.3 \%$ & - \\
\hline vitamin B ${ }_{17}$ intravenous infusion & 2 & $1.3 \%$ & - \\
\hline oxygen therapy & 2 & $1.3 \%$ & 430 \\
\hline ozone therapy - nonspecific & 2 & $1.3 \%$ & - \\
\hline microbeam radiation therapy & 2 & $1.3 \%$ & - \\
\hline coenzyme Q10 intravenous infusion & 2 & $1.3 \%$ & 75 \\
\hline gonotherapy & 1 & $0.7 \%$ & - \\
\hline reiki & 1 & $0.7 \%$ & - \\
\hline reflexology & 1 & $0.7 \%$ & - \\
\hline vitamin intravenous infusions & 1 & $0.7 \%$ & - \\
\hline magnesium intravenous infusion & 1 & $0.7 \%$ & - \\
\hline choline & 1 & $0.7 \%$ & - \\
\hline cobalamin intravenous infusion & 1 & $0.7 \%$ & - \\
\hline vitamin A intravenous infusion & 1 & $0.7 \%$ & - \\
\hline curcumin & $0.7 \%$ & - \\
\hline
\end{tabular}

Table V. Medical specialties of physicians working in CAM institutions

\begin{tabular}{|lll|}
\hline Medical specialty $(\mathbf{n}=\mathbf{8 4})$ & $\mathbf{n}$ & $\%$ \\
\hline general surgery & 10 & $12 \%$ \\
\hline internal medicine & 10 & $12 \%$ \\
\hline family medicine & 6 & $7 \%$ \\
\hline cardiology & 5 & $6 \%$ \\
\hline radiology & 4 & $5 \%$ \\
\hline oncological surgery & 3 & $4 \%$ \\
\hline gynecology & 3 & $4 \%$ \\
\hline plastic surgery & 3 & $4 \%$ \\
\hline dermatology & 3 & $4 \%$ \\
\hline orthopaedics & 3 & $4 \%$ \\
\hline neurology & 3 & $4 \%$ \\
\hline ophthalmology & 2 & $2 \%$ \\
\hline pediatrics & 2 & $2 \%$ \\
\hline oncology & 2 & $2 \%$ \\
\hline esthetic medicine & 2 & $2 \%$ \\
\hline homeopathy & 2 & $2 \%$ \\
\hline emergency medicine & $2 \%$ \\
\hline urology & $2 \%$ \\
\hline
\end{tabular}

\begin{tabular}{|lccc|}
\hline Service & $\mathrm{n}=52$ & $\%$ & $\begin{array}{c}\text { Median } \\
\text { fee per } \\
\text { procedure } \\
\text { (PLN)* }\end{array}$ \\
\hline chelation & 1 & $0.7 \%$ & 160 \\
\hline peptide therapy & 1 & $0.7 \%$ & 475 \\
\hline artesunate & 1 & $0.7 \%$ & - \\
\hline oligonucleotide therapy & 1 & $0.7 \%$ & - \\
\hline intravenous infusion of unknown & 1 & $0.7 \%$ & - \\
\hline composition & 1 & $0.7 \%$ & 100 \\
\hline feet reflexology & 1 & $0.7 \%$ & 100 \\
\hline head and neck reflexology & 1 & $0.7 \%$ & - \\
\hline kangen water & 1 & $0.7 \%$ & - \\
\hline mistletoe therapy & 1 & $0.7 \%$ & - \\
\hline herbal medicine & 1 & $0.7 \%$ & - \\
\hline vibroacoustic therapy & 1 & $0.7 \%$ & - \\
\hline plasmotherapy (Rifle's generator) & 1 & $0.7 \%$ & 350 \\
\hline larvae therapy & 1 & $0.7 \%$ & - \\
\hline rectal ozone therapy & 1 & $0.7 \%$ & - \\
\hline bioelectronics & 1 & $0.7 \%$ & 305 \\
\hline Zapper's biofeedback & & & - \\
\hline
\end{tabular}

${ }^{*} 1 \mathrm{PLN} \approx 0.22$ EUR

\begin{tabular}{|c|c|c|}
\hline Medical specialty $(n=84)$ & $\mathrm{n}$ & $\%$ \\
\hline vascular surgery & 1 & $1 \%$ \\
\hline palliative medicine & 1 & $1 \%$ \\
\hline nuclear medicine & 1 & $1 \%$ \\
\hline infectious diseases & 1 & $1 \%$ \\
\hline osteopathy & 1 & $1 \%$ \\
\hline phlebology & 1 & $1 \%$ \\
\hline anesthesiology and intensive care & 1 & $1 \%$ \\
\hline hyperbaric medicine & 1 & $1 \%$ \\
\hline rheumatology & 1 & $1 \%$ \\
\hline andrology & 1 & $1 \%$ \\
\hline proctology & 1 & $1 \%$ \\
\hline Chinese medicine & 1 & $1 \%$ \\
\hline oncological radiotherapy & 1 & $1 \%$ \\
\hline environmental engineering & 1 & $1 \%$ \\
\hline geriatrics & 1 & $1 \%$ \\
\hline psychiatry & 1 & $1 \%$ \\
\hline endocrinology & 1 & $1 \%$ \\
\hline
\end{tabular}




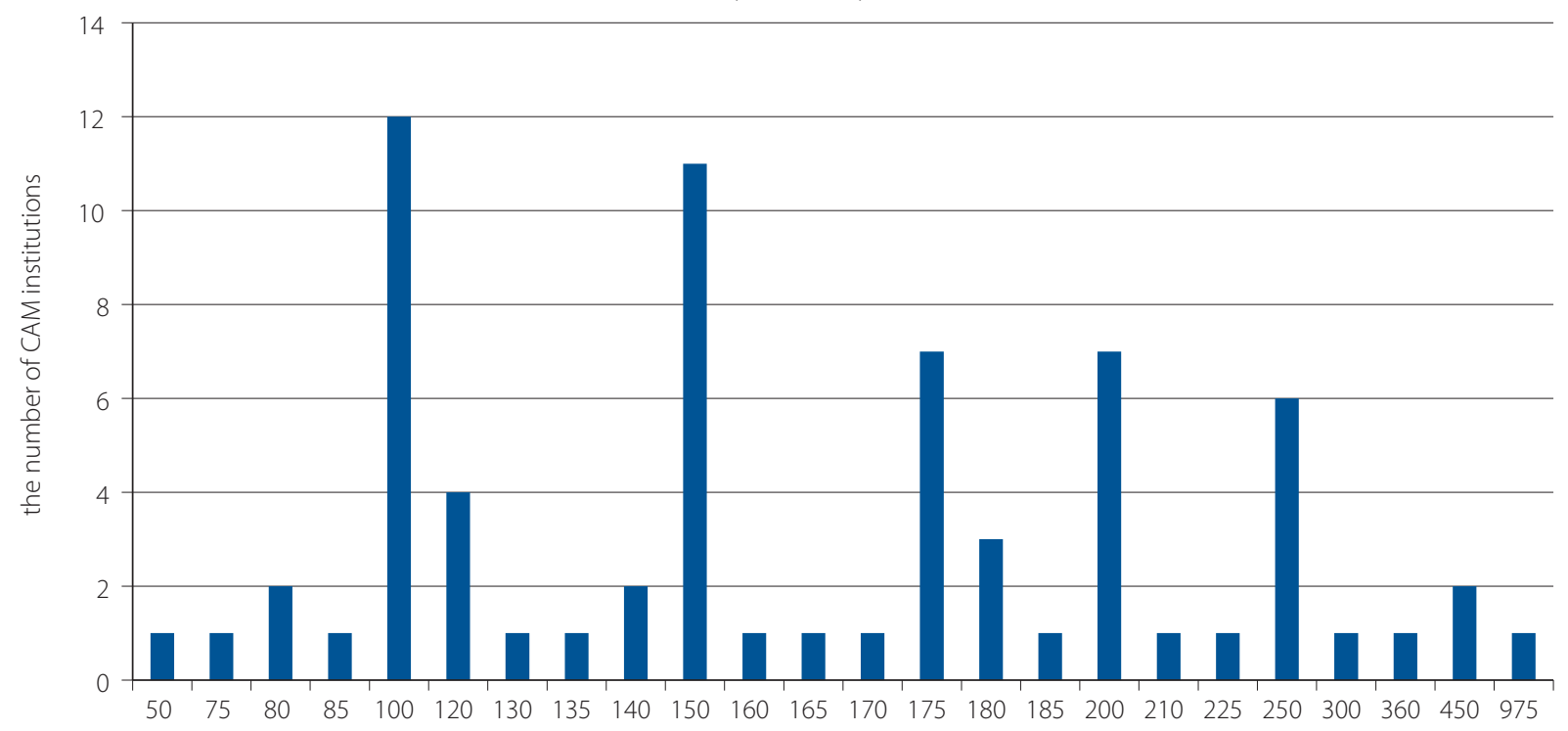

Figure 2. The mean price (PLN) per consultation in CAM institutions $(n=70)$

the mean price $(P L N)$ per procedure

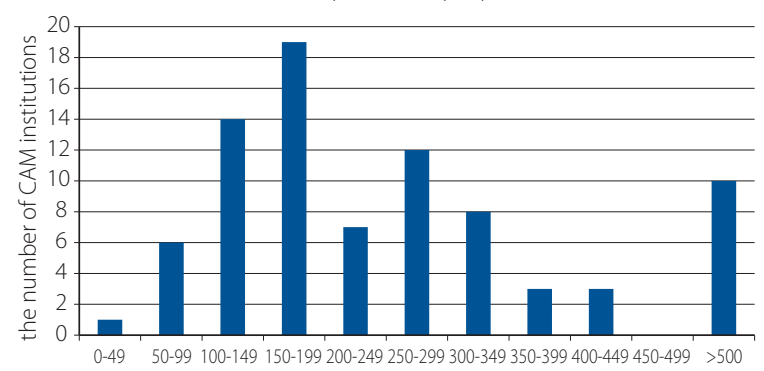

Figure 3. The mean price (PLN) per procedure in CAM institutions $(n=83)$

-based and non-drug-based therapies (38\% vs. 32\%, $p=0.45$ ). The most common physician specialties were general surgery, internal medicine, family medicine, cardiology, and radiology (tab. V). The fees for consultations and procedures were provided by $77 \%$ and $90 \%$ of institutions, respectively. The mean prices for consultations and procedures were 179.43 PLN (standard deviation 122 PLN) and 313 PLN (standard deviation 312 PLN), respectively (fig. 2 and 3). The median fees for cancer and non-cancer consultations were 150 PLN each (ranges: 50-975 PLN and 75-450 PLN, respectively; $P=0.95$ ), whereas the median fee for anticancer therapies was higher than that for non-anticancer therapies (medians: 250 PLN and 170 PLN, respectively, $p=0.041$; ranges: 90-1235 PLN and 45-1625 PLN, respectively). Only $15 \%$ of CAM institutions provided references to published articles when recommending particular services.

\section{Discussion}

To the best of our knowledge, this is the first study to investigate the scope of CAM in Poland. Our analysis demonstrated a wide variety of methods for treating cancer and other chronic diseases. Both the number of methods (18 drug-based and 52 non-drug-based) and the number of treated entities (109) identified in our study are impressive. The vast majority of CAM institutions in Poland are located in large cities, making them easily accessible. Since there is no public funding for CAM services in Poland, all institutions subjected to this analysis were private.

The legal status of CAM in Poland is unregulated, and data on its prevalence are scarce. In the Public Opinion Research Center survey in 2011, 24\% of people admitted that they or a close family member had used the CAM Public Opinion Research Center 2011 [17].

The popularity of CAM among cancer patients in Poland may have several reasons. One of them is the poor general assessment of public cancer care. A study conducted in 2011 on a representative sample of 1000 Poles revealed that only $18 \%$ of responders believed that the available cancer treatment in Poland was of a standard comparable to that of other EU countries [18]. The use of CAM may also result from anxiety and a lack of emotional and psychological support during treatment. Patients often feel alone in coping with the psychological impact of a cancer diagnosis. As opposed to conventional treatment, they view CAM as an effective, safe, and holistic approach. Furthermore, many patients view conventional medicine as an aggressive and isolated treatment (cancer disease similarly to depression in Poland is often stigmatized. In result patients end up alone with the disease) and are afraid of its toxicity [19]. Hence, despite a lack of evidence, alternative methods are frequently used in line to supplement standard treatment to increase overall efficacy and alleviate side effects. Interestingly, until recently, there was a relatively high level of CAM acceptance among Polish physicians. In a survey undertaken in 2008, 42\% of physicians working in oncology departments had recommended at least one CAM method to their patients [20]. However, a more recent study 
showed a higher level of skepticism about the value of CAM, particularly among junior physicians [21].

The primary target of CAM is malignant diseases. A global survey of 61 studies indicated that the prevalence of CAM usage among cancer patients in the second decade of the 21 st century varied from $16.5 \%$ to $93 \%$ (mean 51\%) [22]. Cancer patients demonstrate an increased desire to use CAM, primarily due to their motivation to alleviate treatment-related side effects, boost immunity, and cure the disease $[14,22,23]$. In our study, $41 \%$ of CAM institutions offered anticancer treatment, $46 \%$ provided supportive cancer treatment, and 32\% offered both anticancer and supportive cancer treatment. The high proportion of institutions providing cancer services in this study may bedue to Internet search criteria focused on cancer treatment. In contrast, other CAM-managed diseases were identified unintentionally and may be underreported.

The most common CAM service across all diseases (offered by more than half of institutions) was IVCl. This method was popular among cancer patients. A recent Polish study indicated that the most frequent indications for IVCI therapy were its perceived effectiveness in acting as a potent anticancer agent, enhancing the chemosensitivity of cancer cells, and reducing the intensity of chemotherapy-related toxicities [24]. The widespread use of this method may also be attributed to its ease of access, efficient marketing, as well as common belief that vitamins are generally safe and non-toxic. Other relatively common methods used by cancer patients were saltwater, intravenous infusions of glutathione, colon irrigation, diet, and bioresonance. The most frequent methods used for non-cancer chronic diseases, depending on the diagnosis, included saltwater, bioresonance, IVCl, intravenous infusions of alpha-lipoic acid, intravenous infusion of vitamins other than vitamin $\mathrm{C}$, and colon irrigation.

Several demographic predictors associated with CAM usage were previously identified, (e.g., young age/female sex, higher education, higher income, and history of (AM use). However, since the incidences of cancer and other chronic diseases increase with age, older populations are also frequent CAM users $[22,23]$.

To the best of our knowledge, our study is the first to analyze the costs of CAM services in Poland. The money spent on CAM services often deplete patients'finances; this is especially true for the elderly. The median costs per consultation and procedure were 150 PLN (33 EUR) and 175-245 PLN (39-54 EUR), respectively, which constitute $7.7 \%$ and $16 \%$ of the national average and retirement pension in Poland, respectively $[25,26]$. Notably, most CAM treatments involve repeat visits, which significantly increases the cost of the service. In 2007, the costs of nutrition-based CAM for the top five causes of cancer-related death in the US per month ranged from 4.33 USD to 263 USD (median 27 USD) [27]. CAM-related expenses for cancer patients vary significantly across the world (e.g., Europe,
US, Australia, New Zealand, Turkey), from 4 EUR up to 123 EUR per month [28].

In our study, only 35\% of institutions reported the names and specialties of employed doctors. This may be due to the lack of relevant scientific evidence proving the beneficial effects of their practices or fear of possible legal consequences of CAM practices. The most common medical specialties of CAM practitioners were general surgery and internal medicine. Only $15 \%$ of CAM institutions supported their services with specific references to published articles on their websites, and these articles were often of low quality or reported only preclinical data.

Our study aimed to assess the general scope of the CAM phenomenon in Poland, including the methods and diseases managed by CAM, physicians' involvement in these practices, and the related costs. We recognize that this study has several limitations. Firstly, our analysis was based on an Internet search, which is not fully representative, as some CAM providers may not advertise their services. Secondly, we used a few specific search queries which could misrepresent the prevalence of certain methods. Thirdly, our study provides only a snapshot of the CAM market in Poland. This may likely be a subject with considerable fluctuation (e.g., related to the current COVID-19 pandemic). Due to its design, our study did not address factors associated with patients' willingness to use CAM in Poland and did not attempt to perform a profound and quantitative analysis of the topic or its social, demographic, or psychological background. We also did not measure patients' preferences or their level of satisfaction related to CAM usage. Finally, we did not address the clinical value of particular CAM methods, as this was beyond the scope of our investigation.

\section{Conclusions}

Our study confirms the popularity of CAM in Poland and demonstrates the astonishing number of treated entities and the various CAM practices available to Polish patients. For the first time, we have also provided the cost of these services. These data may prompt future analyses of the medical and economic aspects of this phenomenon. Patients often conceal CAM use from their physicians. Health care professionals should discuss possible CAM use with every patient. It should be an open and nonjudgmental conversation so as to gain trust and encourage patients to share their experiences on CAM use. Patients should be counseled and redirected to evidence-based treatment options and life-style changes which are effective and will not interfere with conventional medicine. Oncologists, but also other medical specialists, should be aware of these recommendations, especially since the widespread use of CAM is prevalent among patients suffering from other chronic diseases.

\section{Acknowledgements}

The study was conducted under the patronage of the Polish Cancer League.

We thank Agastya Patel for proofreading this article. 
Conflict of interest: none declared

\section{Adrian Perdyan}

Medical University of Gdansk

International Research Agenda 3P Medicine Laboratory

ul. Smoluchowskiego 17

80-214, Gdańsk, Poland

e-mail:perdyan.adrian@gumed.edu.pl

Received: 16 Aug 2021

Accepted: 2 Nov 2021

\section{References}

1. Carson JW, Treggiari MM, Mauer KM, et al. Complementary and Alternative Medicine Services at Pain Treatment Clinics: A National Survey of Pain Medicine Specialists in the United States. J Altern Complement Med. 2021; 27(4): 349-351, doi: 10.1089/acm.2020.0487, indexed in Pubmed: 33544018.

2. Adeniyi O, Washington L, Glenn $\mathrm{CJ}$, et al. The use of complementary and alternative medicine among hypertensive and type 2 diabetic patients in Western Jamaica: A mixed methods study. PLoS One. 2021; 16(2): e0245163, doi: 10.1371/journal.pone.0245163, indexed in Pubmed: 33556053.

3. Li H, Kreiner JM, Wong AR, et al. Oral application of Chinese herbal medicine for allergic rhinitis: A systematic review and meta-analysis of randomized controlled trials. Phytother Res. 2021; 35(6): 3113-3129, doi: 10.1002/ptr.7037, indexed in Pubmed: 33533107.

4. Chiao YW, Livneh H, Guo HR, et al. Use of Chinese Herbal Medicines Is Related to a Reduction in Depression Risk Among Patients With Insomnia: A Matched Cohort Study. Front Neurol. 2020; 11: 583485, doi: 10.3389/fneur.2020.583485, indexed in Pubmed: 33551951.

5. Shirvani-Rad S, Tabatabaei-Malazy O, Mohseni S, et al. Probiotics as a Complementary Therapy for Management of Obesity: A Systematic Review. Evid Based Complement Alternat Med. 2021; 2021: 6688450, doi: 10.1155/2021/6688450, indexed in Pubmed: 33552218.

6. Akour A, Abuloha S, Mulakhudair AR, et al. Complementary and alternative medicine for urinary tract illnesses: A cross-sectional survey in Jordan. Complement Ther Clin Pract. 2021; 43: 101321, doi: 10.1016/j. ctcp.2021.101321, indexed in Pubmed: 33548746.

7. Lantos PM, Shapiro ED, Auwaerter PG, et al. Unorthodox alternative therapies marketed to treat Lyme disease. Clin Infect Dis. 2015; 60(12): 1776-1782, doi: 10.1093/cid/civ186, indexed in Pubmed: 25852124.

8. Huebner J, Prott FJ, Muecke R, et al. Prevention and Integrative Oncology of the German Cancer Society Working Group. Economic Evaluation of Complementary and Alternative Medicine in Oncology: Is There a Difference Compared to Conventional Medicine? Med Princ Pract. 2017; 26(1): 41-49, doi: 10.1159/000450645, indexed in Pubmed: 27607437.

9. Silvers WS, Bailey HK. Integrative approach to allergy and asthma using complementary and alternative medicine. Ann Allergy Asthma Immunol. 2014; 112(4): 280-285, doi: 10.1016/j.anai.2014.01.020, indexed in Pubmed: 24679731.

10. Mbizo J, Okafor A, Sutton MA, et al. Complementary and alternative medicine use among persons with multiple chronic conditions: results from the 2012 National Health Interview Survey. BMC Complement Altern Med. 2018; 18(1): 281, doi: 10.1186/s12906-018-2342-2, indexed in Pubmed: 30340577.

11. Lewith G, Stuart B, Chalder T, et al. Complementary and alternative healthcare use by participants in the PACE trial of treatments for chronic fatigue syndrome. J Psychosom Res. 2016; 87: 37-42, doi: 10.1016/j. jpsychores.2016.06.005, indexed in Pubmed: 27411750.
12. John GM, Hershman DL, Falci L, et al. Complementary and alternative medicine use among US cancer survivors. J Cancer Surviv. 2016; 10(5): 850-864, doi: 10.1007/s11764-016-0530-y, indexed in Pubmed: 26920872.

13. Calcagni N, Gana K, Quintard B. A systematic review of complementary and alternative medicine in oncology: Psychological and physical effects of manipulative and body-based practices. PLoS One. 2019; 14(10): e0223564, doi: 10.1371/journal.pone.0223564, indexed in Pubmed: 31622362.

14. Borm KJ, Schiller K, Asadpour R, et al. Complementary and Alternative Medicine in Radiotherapy: A Comprehensive Review. Top Magn Reson Imaging. 2020; 29(3): 149-156, doi: 10.1097/RMR.0000000000000244, indexed in Pubmed: 32568977.

15. Ludmir EB, Jethanandani A, Mainwaring W, et al. The Trials (and Tribulations) of Complementary and Alternative Medicine in Oncology. J Natl Cancer Inst. 2019; 111(12): 1358-1360, doi: 10.1093/jnci/djz117, indexed in Pubmed: 31165160.

16. Knecht K, Kinder D, Stockert A. Biologically-Based Complementary and Alternative Medicine (CAM) Use in Cancer Patients: The Good, the Bad, the Misunderstood. Front Nutr. 2019; 6: 196, doi: 10.3389/ fnut.2019.00196, indexed in Pubmed: 32039227.

17. CBOS report BS/133/2011 in Horoscopes, predictions, talismans- that is magic around us. 8-11 September 2011. https://www.cbos.pl/SPISKOM. POL/2011/K_133_11.PDF (11.05.2021).

18. Jędrzejewski $M$, Thallinger $C$, Mrozik M, et al. Public perception of cancer care in Poland and Austria. Oncologist. 2015; 20(1):28-36, doi: 10.1634/ theoncologist.2014-0226, indexed in Pubmed: 25520325.

19. Scarton LA, Del Fiol G, Oakley-Girvan I, et al. Understanding cancer survivors' information needs and information-seeking behaviors for complementary and alternative medicine from short- to long-term survival: a mixed-methods study. J Med Libr Assoc. 2018; 106(1): 87-97, doi: 10.5195/jmla.2018.200, indexed in Pubmed: 29339938.

20. Duleba K, Wysocki M, Styczyński J. Physicians attitudes towards complementary and alternative medicine in patients with cancer: preliminary report from pediatric and oncology centers. Med Wieku Rozwoj. 2008; 12(4 Pt 2): 1148-1154, indexed in Pubmed: 19531841.

21. Olchowska-Kotala A, Barański J. Polish physicians'attitudes to complementary and alternative medicine. Complement Ther Med. 2016; 27: 51-57, doi: 10.1016/j.ctim.2016.05.004, indexed in Pubmed: 27515876.

22. Keene MR, Heslop IM, Sabesan SS, et al. Complementary and alternative medicine use in cancer: A systematic review. Complement Ther Clin Pract. 2019; 35: 33-47, doi: 10.1016/j.ctcp.2019.01.004, indexed in Pubmed: 31003679.

23. Puskulluoglu M, Uchańska B, Tomaszewski K, et al. Use of complementary and alternative medicine among Polish cancer patients. Nowotwory. Journal of Oncology. 2021;71(5):274-281, doi: 10.5603/njo.a2021.0051.

24. Zasowska-Nowak A, Nowak PJ, Ciałkowska-Rysz A. High-Dose Vitamin C in Advanced-Stage Cancer Patients. Nutrients. 2021; 13(3), doi: 10.3390/ nu13030735, indexed in Pubmed: 33652579.

25. Emerytura 2412 zł (PLN) brutto, ile to netto? 2021 netto-brutto.eu. https://netto-brutto.eu/emerytura/2412 (19.04.2021).

26. 5973 zł brutto ile to netto - umowa o pracę - wynagrodzenia.pl. https:// wynagrodzenia.pl/brutto-netto/umowa-o-prace/5973-brutto-ile-to-netto (19.04.2021).

27. Alsawaf MA, Jatoi A. Shopping for nutrition-based complementary and alternative medicine on the Internet: how much money might cancer patients be spending online? J Cancer Educ. 2007; 22(3): 174-176, doi: 10.1007/BF03174332, indexed in Pubmed: 17760524.

28. Aydin Avci I, Koç Z, Sağlam Z. Use of complementary and alternative medicine by patients with cancer in northern Turkey: analysis of cost and satisfaction. J Clin Nurs. 2012; 21(5-6): 677-688, doi: 10.1111/j.1365-2702.2011.03732.x, indexed in Pubmed: 21714820. 
Supplementary table I. Practices used in the treatment of rheumatic diseases

\begin{tabular}{|lll|}
\hline Method & n & $\%$ \\
\hline ozone therapy & 21 & $21 \%$ \\
\hline bioresonance & 20 & $20 \%$ \\
\hline vitamin C intravenous infusion & 15 & $15 \%$ \\
\hline systemic hyperthermia & 6 & $6.1 \%$ \\
\hline colon irrigation & 5 & $5.1 \%$ \\
\hline alpha-lipoic acid intravenous infusion & 4 & $4.1 \%$ \\
\hline hyperbaric chamber & 3 & $3.1 \%$ \\
\hline acupuncture & 3 & $3.1 \%$ \\
\hline vitamin intravenous infusion (other than vitamin C) & 2 & $2.0 \%$ \\
\hline intravenous infusion of glutathione & 2 & $2.0 \%$ \\
\hline medical leeches & 2 & $2.0 \%$ \\
\hline electromagnetic waves & 2 & $2.0 \%$ \\
\hline energy therapy & 1 & $1.0 \%$ \\
\hline diet & 1 & $1.0 \%$ \\
\hline reflexology & 1 & $1.0 \%$ \\
\hline chelation & 1 & $1.0 \%$ \\
\hline vibroacoustic therapy & 1 & $1.0 \%$ \\
\hline matrix regenerating therapy & 1 & $1.0 \%$ \\
\hline physiotherapy & 1 & $1.0 \%$ \\
\hline moxibustion & 1 & $1.0 \%$ \\
\hline massage & 1 & $1.0 \%$ \\
\hline viofor magnetic field therapy & 1 & $1.0 \%$ \\
\hline naturopathy & 1 & $1.0 \%$ \\
\hline ion detox - feet soaking in saltwater & $1.0 \%$ \\
\hline biofeedback & $1.0 \%$ \\
\hline
\end{tabular}

Supplementary table II. Methods used in the treatment of chronic fatigue syndrome

\begin{tabular}{|lcc|}
\hline Method & $\mathrm{n}$ & $\%$ \\
\hline Ozone therapy & 14 & $23 \%$ \\
\hline bioresonance & 9 & $15 \%$ \\
\hline vitamin intravenous infusion (other than vitamin C) & 8 & $13 \%$ \\
\hline intravenous infusion of glutathione & 6 & $10 \%$ \\
\hline colon irrigation & 6 & $10 \%$ \\
\hline alpha-lipoic acid intravenous infusion & 3 & $5.0 \%$ \\
\hline moxibustion & 3 & $5.0 \%$ \\
\hline systemic hyperthermia & 2 & $3.3 \%$ \\
\hline electromagnetic waves & 2 & $3.3 \%$ \\
\hline vitamin Cintravenous infusion & 1 & $1.7 \%$ \\
\hline diet & 1 & $1.7 \%$ \\
\hline oxygen therapy & 1 & $1.7 \%$ \\
\hline herbal medicine & 1 & $1.7 \%$ \\
\hline biofeedback & 1 & $1.7 \%$ \\
\hline naturopathy & 1 & $1.7 \%$ \\
\hline ion detox - feet soaking in saltwater & 1 & $1.7 \%$ \\
\hline
\end{tabular}

Supplementary table III. Methods used in the treatment of diabetes

\begin{tabular}{|c|c|c|}
\hline Method & $n$ & $\%$ \\
\hline ozone therapy & 21 & $24 \%$ \\
\hline alpha-lipoic acid intravenous infusion & 17 & $20 \%$ \\
\hline vitamin $C$ intravenous infusion & 11 & $13 \%$ \\
\hline bioresonance & 11 & $13 \%$ \\
\hline intravenous infusion of coenzyme Q10 & 5 & $5.8 \%$ \\
\hline hyperbaric chamber & 3 & $3.5 \%$ \\
\hline chelation & 3 & $3.5 \%$ \\
\hline systemic hyperthermia & 2 & $2.3 \%$ \\
\hline vitamin intravenous infusion (other than vitamin C) & 2 & $2.3 \%$ \\
\hline oxygen therapy & 2 & $2.3 \%$ \\
\hline intravenous infusion of glutathione & 1 & $1.2 \%$ \\
\hline vibroacoustic therapy & 1 & $1.2 \%$ \\
\hline medical leeches & 1 & $1.2 \%$ \\
\hline physiotherapy & 1 & $1.2 \%$ \\
\hline fotostimulation & 1 & $1.2 \%$ \\
\hline massage & 1 & $1.2 \%$ \\
\hline viofor magnetic field therapy & 1 & $1.2 \%$ \\
\hline naturotherapy & 1 & $1.2 \%$ \\
\hline electromagnetic waves & 1 & $1.2 \%$ \\
\hline
\end{tabular}

Supplementary table IV. Methods used in the treatment of allergies

\begin{tabular}{|lcc|}
\hline Method & $\mathrm{n}$ & $\%$ \\
\hline bioresonance & 24 & $38 \%$ \\
\hline ozone therapy & 12 & $19 \%$ \\
\hline vitamin C intravenous infusion & 6 & $9.5 \%$ \\
\hline colon irrigation & 6 & $9.5 \%$ \\
\hline vitamin intravenous infusion (other than vitamin C) & 2 & $3.2 \%$ \\
\hline matrix regenerating therapy & 2 & $3.2 \%$ \\
\hline systemic hyperthermia & 1 & $1.6 \%$ \\
\hline reflexology & 1 & $1.6 \%$ \\
\hline chelation & 1 & $1.6 \%$ \\
\hline oxygen therapy & 1 & $1.6 \%$ \\
\hline kangen water & 1 & $1.6 \%$ \\
\hline herbal medicine & 1 & $1.6 \%$ \\
\hline medical leeches & 1 & $1.6 \%$ \\
\hline biofeedback & 1 & $1.6 \%$ \\
\hline naturopathy & 1 & $1.6 \%$ \\
\hline ion detox - feet soaking in saltwater & 1 & $1.6 \%$ \\
\hline electromagnetic waves & 1 & $1.6 \%$ \\
\hline
\end{tabular}


Supplementary table V. Methods used in the treatment of borreliosis

\begin{tabular}{|lcl|}
\hline Method & n & $\%$ \\
\hline bioresonance & 25 & $29 \%$ \\
\hline ozone therapy & 21 & $25 \%$ \\
\hline vitamin C intravenous infusion & 11 & $13 \%$ \\
\hline systemic hyperthermia & 4 & $4.7 \%$ \\
\hline vitamin intravenous infusion (other than vitamin C) & 4 & $4.7 \%$ \\
\hline herbal medicine & 4 & $4.7 \%$ \\
\hline diet & 3 & $3.5 \%$ \\
\hline hyperbaric chamber & 3 & $3.5 \%$ \\
\hline alpha-lipoic acid intravenous infusion & 2 & $2.4 \%$ \\
\hline intravenous infusion of glutathione & 1 & $1.2 \%$ \\
\hline homeopathy & 1 & $1.2 \%$ \\
\hline physiotherapy & 1 & $1.2 \%$ \\
\hline fotostimulation & 1 & $1.2 \%$ \\
\hline massage & 1 & $1.2 \%$ \\
\hline viofor magnetic field therapy & 1 & $1.2 \%$ \\
\hline naturopathy & 1 & $1.2 \%$ \\
\hline electromagnetic waves & $1.2 \%$ \\
\hline
\end{tabular}

Supplementary table VI. Methods used in the treatment of arterial hypertension

\begin{tabular}{|lcc|}
\hline Method & n & $\%$ \\
\hline vitamin C intravenous infusion & 13 & $19 \%$ \\
\hline ozone therapy & 10 & $15 \%$ \\
\hline colon irrigation & 6 & $8.8 \%$ \\
\hline bioresonance & 4 & $5.9 \%$ \\
\hline alpha-lipoic acid intravenous infusion & 4 & $5.9 \%$ \\
\hline systemic hyperthermia & 3 & $4.4 \%$ \\
\hline vitamin intravenous infusion (other than vitamin C) & 3 & $4.4 \%$ \\
\hline hyperbaric chamber & 3 & $4.4 \%$ \\
\hline medical leeches & 3 & $4.4 \%$ \\
\hline intravenous infusion of coenzyme Q10 & 3 & $4.4 \%$ \\
\hline acupuncture & 3 & $4.4 \%$ \\
\hline chelation & 2 & $2.9 \%$ \\
\hline reflexology & 1 & $1.5 \%$ \\
\hline herbal medicine & 1 & $1.5 \%$ \\
\hline vibroacoustic therapy & $1.5 \%$ \\
\hline biofeedback & 1 & $1.5 \%$ \\
\hline hypnosis & $1.5 \%$ \\
\hline physiotherapy & $1.5 \%$ \\
\hline fotostimulation & 1 & $1.5 \%$ \\
\hline massage & $1.5 \%$ \\
\hline viofor magnetic field therapy & 1 & $1.5 \%$ \\
\hline naturopathy & 1 & $1.5 \%$ \\
\hline electromagnetic waves & 1 & $1.5 \%$ \\
\hline
\end{tabular}

Supplementary table VII. Methods used in the treatment of depression

\begin{tabular}{|c|c|c|}
\hline Method & n & $\%$ \\
\hline bioresonance & 16 & $23 \%$ \\
\hline vitamin C intravenous infusion & 10 & $15 \%$ \\
\hline vitamin intravenous infusions (other than vitamin C) & 7 & $10 \%$ \\
\hline colon irrigation & 7 & $10 \%$ \\
\hline hyperbaric chamber & 4 & $5.8 \%$ \\
\hline diet & 2 & $2.9 \%$ \\
\hline ozone therapy & 2 & $2.9 \%$ \\
\hline alpha-lipoic acid intravenous infusion & 2 & $2.9 \%$ \\
\hline matrix regenerating therapy & 2 & $2.9 \%$ \\
\hline homeopathy & 2 & $2.9 \%$ \\
\hline electromagnetic waves & 2 & $2.9 \%$ \\
\hline systemic hyperthermia & 1 & $1.4 \%$ \\
\hline energy medicine & 1 & $1.4 \%$ \\
\hline reflexology & 1 & $1.4 \%$ \\
\hline intravenous infusion of glutathione & 1 & $1.4 \%$ \\
\hline chelation & 1 & $1.4 \%$ \\
\hline oxygen therapy & 1 & $1.4 \%$ \\
\hline medical leeches & 1 & $1.4 \%$ \\
\hline acupuncture & 1 & $1.4 \%$ \\
\hline hypnosis & 1 & $1.4 \%$ \\
\hline physiotherapy & 1 & $1.4 \%$ \\
\hline moxibustion & 1 & $1.4 \%$ \\
\hline massage & 1 & $1.4 \%$ \\
\hline naturopathy & 1 & $1.4 \%$ \\
\hline
\end{tabular}

Supplementary table VIII. Methods used in the treatment of chronic infections

\begin{tabular}{|lll|}
\hline Method & n & $\%$ \\
\hline vitamin C intravenous infusion & 16 & $21 \%$ \\
\hline bioresonance & 16 & $21 \%$ \\
\hline ozone therapy & 15 & $19 \%$ \\
\hline colon irrigation & 7 & $9.0 \%$ \\
\hline alpha-lipoic acid intravenous infusion & 5 & $6.4 \%$ \\
\hline intravenous infusion of glutathione & 4 & $5.1 \%$ \\
\hline vitamin intravenous infusion (other than vitamin C) & 3 & $3.8 \%$ \\
\hline oxygen therapy & 2 & $2.6 \%$ \\
\hline systemic hyperthermia & 1 & $1.3 \%$ \\
\hline diet & 1 & $1.3 \%$ \\
\hline reflexology & 1 & $1.3 \%$ \\
\hline herbal medicine & 1 & $1.3 \%$ \\
\hline matrix regenerating therapy & 1 & $1.3 \%$ \\
\hline intravenous infusion of coenzyme Q10 & 1 & $1.3 \%$ \\
\hline acupuncture & $1.3 \%$ \\
\hline naturopathy & 1 & $1.3 \%$ \\
\hline ion detox - feet soaking in saltwater & $1.3 \%$ \\
\hline electromagnetic waves & $1.3 \%$ \\
\hline
\end{tabular}


Supplementary table IX. Methods used in the treatment of atherosclerosis

\begin{tabular}{lll}
\hline Method & n & $\%$ \\
\hline Ozone therapy & 17 & $22 \%$ \\
\hline vitamin C & 13 & $17 \%$ \\
\hline alpha-lipoic acid intravenous infusion & 11 & $14 \%$ \\
\hline chelation & 8 & $10 \%$ \\
\hline bioresonance & 6 & $7.8 \%$ \\
\hline hyperbaric chamber & 3 & $3.9 \%$ \\
\hline intravenous infusion of glutathione & 3 & $3.9 \%$ \\
\hline colon irrigation & 3 & $3.9 \%$ \\
\hline intravenous infusion of coenzyme Q10 & 3 & $3.9 \%$ \\
\hline medical leeches & 2 & $2.6 \%$ \\
\hline electromagnetic waves & 2 & $2.6 \%$ \\
\hline vitamin intravenous infusions (other than & 2 & $2.6 \%$ \\
\hline vitamin C) & & \\
\hline systemic hyperthermia & 1 & $1.3 \%$ \\
\hline oxygen therapy & 1 & $1.3 \%$ \\
\hline dimethyl sulfoxide & 1 & $1.3 \%$ \\
\hline naturopathy & $1.3 \%$ \\
\hline
\end{tabular}

Supplementary table X. Diseases treated by intravenous vitamin C infusion

\begin{tabular}{|c|c|c|}
\hline Diseases & $n$ & $\%$ \\
\hline anticancer therapy & 28 & $11 \%$ \\
\hline chronic infections & 24 & $9.5 \%$ \\
\hline supportive cancer therapy & 18 & $7.1 \%$ \\
\hline oxidative stress & 18 & $7.1 \%$ \\
\hline arterial hypertension & 15 & $5.9 \%$ \\
\hline heart diseases & 14 & $5.5 \%$ \\
\hline rheumatic diseases & 13 & $5.1 \%$ \\
\hline chronic fatigue syndrome & 10 & $4.0 \%$ \\
\hline diabetes & 9 & $3.6 \%$ \\
\hline immunity deficiency & 9 & $3.6 \%$ \\
\hline allergies & 7 & $2.8 \%$ \\
\hline borreliosis & 6 & $2.4 \%$ \\
\hline depression & 6 & $2.4 \%$ \\
\hline candidiasis & 6 & $2.4 \%$ \\
\hline atherosclerosis & 5 & $2.0 \%$ \\
\hline parasitic diseases & 5 & $2.0 \%$ \\
\hline viral hepatitis & 5 & $2.0 \%$ \\
\hline cardiovascular diseases & 5 & $2.0 \%$ \\
\hline pain from various origins & 4 & $1.6 \%$ \\
\hline cataract & 4 & $1.6 \%$ \\
\hline heavy metals or mushroom intoxication & 4 & $1.6 \%$ \\
\hline myocardial infarction & 4 & $1.6 \%$ \\
\hline heart arrhythmia & 4 & $1.6 \%$ \\
\hline chronic diseases & 4 & $1.6 \%$ \\
\hline asthma & 3 & $1.2 \%$ \\
\hline atopic dermatitis, psoriasis & 3 & $1.2 \%$ \\
\hline hepatic diseases & 2 & $0.8 \%$ \\
\hline
\end{tabular}

\begin{tabular}{|lll|}
\hline Diseases & n & $\%$ \\
\hline multiple sclerosis & 2 & $0.8 \%$ \\
\hline autoimmune diseases & 2 & $0.8 \%$ \\
\hline viral diseases & 2 & $0.8 \%$ \\
\hline Alzheimer's disease & 2 & $0.8 \%$ \\
\hline intermittent claudication & 1 & $0.4 \%$ \\
\hline migraine & 1 & $0.4 \%$ \\
\hline osteoporosis & 1 & $0.4 \%$ \\
\hline neuropathies & 1 & $0.4 \%$ \\
\hline sciatica & 1 & $0.4 \%$ \\
\hline impotence & 1 & $0.4 \%$ \\
\hline ulcerative colitis, Crohn disease & 1 & $0.4 \%$ \\
\hline thyroid diseases & 1 & $0.4 \%$ \\
\hline Parkinson's disease & 1 & $0.4 \%$ \\
\hline absorption disorders & 1 & $0.4 \%$ \\
\hline
\end{tabular}

Supplementary table $\mathbf{X I}$. Diseases treated by bioresonance

\begin{tabular}{|c|c|c|}
\hline Diseases & $\mathrm{n}$ & $\%$ \\
\hline allergies & 25 & $6.9 \%$ \\
\hline borreliosis & 22 & $6.0 \%$ \\
\hline addiction treatment & 22 & $6.0 \%$ \\
\hline pain from various origins & 21 & $5.8 \%$ \\
\hline chronic infections & 21 & $5.8 \%$ \\
\hline candidiasis & 20 & $5.5 \%$ \\
\hline parasitic diseases & 15 & $4.1 \%$ \\
\hline rheumatic diseases & 13 & $3.6 \%$ \\
\hline depression & 12 & $3.3 \%$ \\
\hline obesity & 12 & $3.3 \%$ \\
\hline migraine & 11 & $3.0 \%$ \\
\hline heavy metals or mushroom intoxication & 11 & $3.0 \%$ \\
\hline chronic fatigue syndrome & 9 & $2.5 \%$ \\
\hline diabetes & 8 & $2.2 \%$ \\
\hline asthma & 7 & $1.9 \%$ \\
\hline immunity deficiency & 7 & $1.9 \%$ \\
\hline ulcerative colitis, Crohn disease & 7 & $1.9 \%$ \\
\hline atopic dermatitis, psoriasis & 7 & $1.9 \%$ \\
\hline autoimmune diseases & 6 & $1.6 \%$ \\
\hline neurological disorders & 6 & $1.6 \%$ \\
\hline arterial hypertension & 5 & $1.4 \%$ \\
\hline hormonal diseases & 5 & $1.4 \%$ \\
\hline hepatic diseases & 4 & $1.1 \%$ \\
\hline sciatica & 4 & $1.1 \%$ \\
\hline multiple sclerosis & 4 & $1.1 \%$ \\
\hline gastric and duodenal ulcers & 4 & $1.1 \%$ \\
\hline anticancer therapy & 4 & $1.1 \%$ \\
\hline chronic diseases & 4 & $1.1 \%$ \\
\hline atherosclerosis & 3 & $0.8 \%$ \\
\hline
\end{tabular}


Supplementary table XI. cont. Diseases treated by bioresonance Services offered by CAM institutions for cancer patients

\begin{tabular}{|c|c|c|c|c|c|}
\hline Diseases & $\mathbf{n}$ & $\%$ & Diseases & $\mathbf{n}$ & $\%$ \\
\hline osteoporosis & 3 & $0.8 \%$ & attention deficit hyperactivity disorder & 2 & $0.5 \%$ \\
\hline ischemic stroke & 3 & $0.8 \%$ & coronary artery disease & 1 & $0.3 \%$ \\
\hline chronic inflammation of the urethra and prostate & 3 & $0.8 \%$ & neuropathies & 1 & $0.3 \%$ \\
\hline thyroid diseases & 3 & $0.8 \%$ & chronic gastritis & 1 & $0.3 \%$ \\
\hline cardiovascular diseases & 3 & $0.8 \%$ & herpetic lesions & 1 & $0.3 \%$ \\
\hline other (everything) & 3 & $0.8 \%$ & anemia & 1 & $0.3 \%$ \\
\hline supportive cancer therapy & 3 & $0.8 \%$ & pneumonia, bronchitis & 1 & $0.3 \%$ \\
\hline intermittent claudication & 2 & $0.5 \%$ & autism & 1 & $0.3 \%$ \\
\hline acne & 2 & $0.5 \%$ & chickenpox, shingles & 1 & $0.3 \%$ \\
\hline irritable bowel syndrome & 2 & $0.5 \%$ & myocardial infarction & 1 & $0.3 \%$ \\
\hline infertility & 2 & $0.5 \%$ & thromboembolism & 1 & $0.3 \%$ \\
\hline heart diseases & 2 & $0.5 \%$ & kidney diseases & 1 & $0.3 \%$ \\
\hline eye diseases & 2 & $0.5 \%$ & Parkinson's disease & 1 & $0.3 \%$ \\
\hline pancreatic function disorders & 2 & $0.5 \%$ & absorption disorders & 1 & $0.3 \%$ \\
\hline bedsores, burns, ulcers & 2 & $0.5 \%$ & inflammation of the reproductive organs & 1 & $0.3 \%$ \\
\hline viral hepatitis & 2 & $0.5 \%$ & hemorrhoids & 1 & $0.3 \%$ \\
\hline digestive system diseases & 2 & $0.5 \%$ & infertility & 1 & $0.3 \%$ \\
\hline viral diseases & 2 & $0.5 \%$ & respiratory system diseases & 1 & $0.3 \%$ \\
\hline chronic obstructive pulmonary disease & 2 & $0.5 \%$ & bile ducts and gall bladder inflammation & 1 & $0.3 \%$ \\
\hline
\end{tabular}

Supplementary table XII. Frequency of drug-based and non-drug based methods in the treatment of non-cancer diseases

\begin{tabular}{|c|c|c|c|c|c|c|c|}
\hline & \multicolumn{3}{|c|}{$\begin{array}{l}\text { Drug-based } \\
\qquad(n=61)\end{array}$} & \multicolumn{2}{|c|}{$\begin{array}{l}\text { Non-drug based } \\
\quad(n=73)\end{array}$} & \multicolumn{2}{|c|}{ z-test } \\
\hline & $n$ & $\mathrm{n}$ & $\%$ & n & $\%$ & statistic & p \\
\hline rheumatic diseases & 53 & 37 & $61 \%$ & 47 & $64 \%$ & 0.444 & 0.6599 \\
\hline chronic fatigue syndrome & 51 & 39 & $64 \%$ & 42 & $58 \%$ & 0.755 & 0.4533 \\
\hline arterial hypertension & 45 & 33 & $54 \%$ & 38 & $52 \%$ & 0.236 & 0.8103 \\
\hline allergies & 45 & 23 & $38 \%$ & 43 & $59 \%$ & 2.444 & 0.0147 \\
\hline borreliosis & 44 & 28 & $46 \%$ & 43 & $59 \%$ & 1.502 & 0.1336 \\
\hline diabetes & 43 & 35 & $57 \%$ & 35 & $48 \%$ & 1.089 & 0.2757 \\
\hline atherosclerosis & 43 & 35 & $57 \%$ & 37 & $51 \%$ & 0.774 & 0.4413 \\
\hline depression & 42 & 29 & $48 \%$ & 37 & $51 \%$ & 0.363 & 0.7188 \\
\hline chronic infections & 42 & 27 & $44 \%$ & 36 & $49 \%$ & 0.584 & 0.5619 \\
\hline migraine & 40 & 25 & $41 \%$ & 37 & $51 \%$ & 1.122 & 0.2627 \\
\hline obesity & 39 & 24 & $39 \%$ & 34 & $47 \%$ & 0.841 & 0.4009 \\
\hline pain from various origins & 39 & 23 & $38 \%$ & 37 & $51 \%$ & 1.505 & 0.1336 \\
\hline hepatic diseases & 37 & 28 & $46 \%$ & 30 & $41 \%$ & 0.559 & 0.5755 \\
\hline atopic dermatitis, psoriasis & 36 & 25 & $41 \%$ & 33 & $45 \%$ & 0.491 & 0.6214 \\
\hline asthma & 35 & 24 & $39 \%$ & 30 & $41 \%$ & 0.206 & 0.8337 \\
\hline addiction & 33 & 14 & $23 \%$ & 31 & $43 \%$ & 2.382 & 0.0173 \\
\hline acne & 31 & 25 & $41 \%$ & 26 & $36 \%$ & 0.637 & 0.5222 \\
\hline immunity deficiency & 31 & 17 & $28 \%$ & 28 & $38 \%$ & 1.28 & 0.2005 \\
\hline ulcerative colitis, Crohn disease & 31 & 22 & $36 \%$ & 28 & $38 \%$ & 0.273 & 0.7872 \\
\hline candidiasis & 30 & 15 & $25 \%$ & 29 & $40 \%$ & 1.858 & 0.0629 \\
\hline heavy metals or mushroom intoxication & 30 & 21 & $34 \%$ & 25 & $34 \%$ & 0.022 & 0.984 \\
\hline
\end{tabular}


Supplementary table XII. cont. Frequency of drug-based and non-drug based methods in the treatment of non-cancer diseases

\begin{tabular}{|c|c|c|c|c|c|c|c|}
\hline & \multicolumn{3}{|c|}{$\begin{array}{l}\text { Drug-based } \\
\qquad(n=61)\end{array}$} & \multicolumn{2}{|c|}{$\begin{array}{l}\text { Non-drug based } \\
\qquad(n=73)\end{array}$} & \multicolumn{2}{|c|}{ z-test } \\
\hline & $\mathrm{n}$ & $n$ & $\%$ & $n$ & $\%$ & statistic & $\mathbf{p}$ \\
\hline oxidative stress & 29 & 28 & $46 \%$ & 19 & $26 \%$ & 2.401 & 0.0164 \\
\hline neurological disorders & 29 & 18 & $30 \%$ & 29 & $40 \%$ & 1.234 & 0.2187 \\
\hline parasitic diseases & 26 & 11 & $18 \%$ & 26 & $36 \%$ & 2.267 & 0.0232 \\
\hline hangover & 25 & 25 & $41 \%$ & 11 & $15 \%$ & 3.37 & 0.0008 \\
\hline coronary artery disease & 23 & 19 & $31 \%$ & 19 & $26 \%$ & 0.655 & 0.5157 \\
\hline multiple sclerosis & 22 & 18 & $30 \%$ & 20 & $27 \%$ & 0.27 & 0.7872 \\
\hline autoimmune diseases & 22 & 17 & $28 \%$ & 19 & $26 \%$ & 0.24 & 0.8103 \\
\hline bedsores, burns, ulcers & 22 & 15 & $25 \%$ & 20 & $27 \%$ & 0.368 & 0.7114 \\
\hline ischemic stroke & 21 & 18 & $30 \%$ & 19 & $26 \%$ & 0.449 & 0.6527 \\
\hline impotence & 20 & 16 & $26 \%$ & 16 & $22 \%$ & 0.583 & 0.5619 \\
\hline irritable bowel syndrome & 19 & 8 & $13 \%$ & 17 & $23 \%$ & 1.505 & 0.131 \\
\hline cardiovascular diseases & 19 & 13 & $21 \%$ & 17 & $23 \%$ & 0.273 & 0.7872 \\
\hline heart diseases & 18 & 15 & $25 \%$ & 14 & $19 \%$ & 0.758 & 0.4473 \\
\hline gastric and duodenal ulcers & 18 & 10 & $16 \%$ & 17 & $23 \%$ & 0.991 & 0.3222 \\
\hline Alzheimer's disease & 16 & 15 & $25 \%$ & 13 & $18 \%$ & 0.962 & 0.3371 \\
\hline myocardial infarction & 16 & 15 & $25 \%$ & 12 & $16 \%$ & 1.172 & 0.242 \\
\hline pneumonia, bronchitis & 15 & 10 & $16 \%$ & 15 & $21 \%$ & 0.615 & 0.5419 \\
\hline $\begin{array}{l}\text { chronic inflammation of the urethra and } \\
\text { prostate }\end{array}$ & 14 & 8 & $13 \%$ & 14 & $19 \%$ & 0.944 & 0.3472 \\
\hline thyroid diseases & 14 & 9 & $15 \%$ & 12 & $16 \%$ & 0.267 & 0.7872 \\
\hline intermittent claudication & 13 & 8 & $13 \%$ & 10 & $14 \%$ & 0.099 & 0.9203 \\
\hline gout & 13 & 11 & $18 \%$ & 13 & $18 \%$ & 0.034 & 0.9761 \\
\hline Parkinson's disease & 13 & 12 & $20 \%$ & 12 & $16 \%$ & 0.486 & 0.6241 \\
\hline osteoporosis & 12 & 12 & $20 \%$ & 9 & $12 \%$ & 1.165 & 0.246 \\
\hline Hashimoto's disease & 12 & 10 & $16 \%$ & 11 & $15 \%$ & 0.21 & 0.8337 \\
\hline sciatica & 12 & 2 & $3.3 \%$ & 12 & $16 \%$ & 2.48 & 0.0131 \\
\hline chronic gastritis & 11 & 6 & $9.8 \%$ & 11 & $15 \%$ & 0.906 & 0.3628 \\
\hline eye diseases & 11 & 4 & $6.6 \%$ & 11 & $15 \%$ & 1.556 & 0.1188 \\
\hline pancreatic function disorders & 11 & 8 & $13 \%$ & 10 & $14 \%$ & 0.099 & 0.9203 \\
\hline fibromyalgia & 10 & 9 & $15 \%$ & 9 & $12 \%$ & 0.41 & 0.6818 \\
\hline thromboembolism & 10 & 7 & $12 \%$ & 9 & $12 \%$ & 0.152 & 0.8808 \\
\hline autism & 9 & 7 & $12 \%$ & 8 & $11 \%$ & 0.094 & 0.9283 \\
\hline endocrine disorders & 9 & 3 & $4.9 \%$ & 8 & $11 \%$ & 1.269 & 0.2041 \\
\hline kidney diseases & 9 & 6 & $9.8 \%$ & 8 & $11 \%$ & 0.212 & 0.8337 \\
\hline digestive system diseases & 9 & 5 & $8.2 \%$ & 9 & $12 \%$ & 0.779 & 0.4354 \\
\hline herpes & 8 & 5 & $8.2 \%$ & 8 & $11 \%$ & 0.538 & 0.5892 \\
\hline anemia & 8 & 6 & $9.8 \%$ & 7 & $9.6 \%$ & 1.427 & 0.1527 \\
\hline varicose veins & 8 & 5 & $8.2 \%$ & 8 & $11 \%$ & 0.538 & 0.5892 \\
\hline food intolerances & 7 & 5 & $8.2 \%$ & 7 & $9.6 \%$ & 0.281 & 0.7795 \\
\hline cataract & 7 & 7 & $12 \%$ & 6 & $8.2 \%$ & 0.634 & 0.5287 \\
\hline tinnitus & 7 & 7 & $12 \%$ & 6 & $8.2 \%$ & 0.634 & 0.5287 \\
\hline viral hepatitis & 7 & 5 & $8.2 \%$ & 7 & $9.6 \%$ & 0.281 & 0.7795 \\
\hline paralysis & 6 & 1 & $1.6 \%$ & 6 & $8.2 \%$ & 1.705 & 0.0891 \\
\hline
\end{tabular}


Supplementary table XII. cont. Frequency of drug-based and non-drug based methods in the treatment of non-cancer diseases

\begin{tabular}{|c|c|c|c|c|c|c|c|}
\hline & \multicolumn{3}{|c|}{$\begin{array}{l}\text { Drug-based } \\
\qquad(n=61)\end{array}$} & \multicolumn{2}{|c|}{$\begin{array}{l}\text { Non-drug based } \\
(n=73)\end{array}$} & \multicolumn{2}{|c|}{ z-test } \\
\hline & $\mathbf{n}$ & $\mathbf{n}$ & $\%$ & $n$ & $\%$ & statistic & $p$ \\
\hline heart arrhythmia & 6 & 5 & $8.2 \%$ & 4 & $5.5 \%$ & 0.626 & 0.5287 \\
\hline hemorrhoids & 6 & 3 & $4.9 \%$ & 6 & $8.2 \%$ & 0.76 & 0.4473 \\
\hline colon dysfunction & 6 & 1 & $1.6 \%$ & 6 & $8.2 \%$ & 1.705 & 0.0891 \\
\hline respiratory system diseases & 6 & 4 & $6.6 \%$ & 6 & $8.2 \%$ & 0.365 & 0.7188 \\
\hline deafness, hearing loss & 5 & 5 & $8.2 \%$ & 5 & $6.0 \%$ & 0.296 & 0.7642 \\
\hline inflammation of female reproductive organs & 5 & 3 & $4.90 \%$ & 5 & $6.8 \%$ & 0.47 & 0.6384 \\
\hline infertility & 5 & 2 & $3.3 \%$ & 5 & $6.8 \%$ & 0.925 & 0.3524 \\
\hline sterility & 4 & 2 & $3.3 \%$ & 3 & $4.1 \%$ & 0.253 & 0.8026 \\
\hline chickenpox & 4 & 2 & $3.3 \%$ & 4 & $5.5 \%$ & 0.613 & 0.5419 \\
\hline $\begin{array}{l}\text { human immunodeficiency virus infection/ } \\
\text { AIDS }\end{array}$ & 4 & 3 & $4.9 \%$ & 3 & $4.1 \%$ & 0.225 & 0.8181 \\
\hline cerebral palsy & 4 & 4 & $6.6 \%$ & 4 & $5.5 \%$ & 0.262 & 0.7949 \\
\hline chronic diseases & 4 & 2 & $3.3 \%$ & 3 & $4.1 \%$ & 0.253 & 0.8026 \\
\hline neuropathies & 3 & 2 & $3.3 \%$ & 3 & $4.1 \%$ & 0.253 & 0.8026 \\
\hline bedwetting & 3 & 0 & $0.0 \%$ & 3 & $4.1 \%$ & 1.601 & 0.1096 \\
\hline bile ducts and gall bladder inflammation & 3 & 2 & $3.3 \%$ & 3 & $4.1 \%$ & 0.253 & 0.8026 \\
\hline posture defects & 2 & 1 & $1.6 \%$ & 2 & $2.7 \%$ & 0.429 & 0.6672 \\
\hline heart defects & 2 & 1 & $1.6 \%$ & 2 & $2.7 \%$ & 0.429 & 0.6672 \\
\hline endometriosis & 2 & 1 & $1.6 \%$ & 2 & $2.7 \%$ & 0.429 & 0.6672 \\
\hline cellulite, stretch marks, scars & 2 & 2 & $3.3 \%$ & 1 & $1.4 \%$ & 0.744 & 0.4593 \\
\hline $\begin{array}{l}\text { acute and chronic inflammation of } \\
\text { reproductive organs }\end{array}$ & 2 & 2 & $3.3 \%$ & 2 & $2.7 \%$ & 0.183 & 0.8572 \\
\hline neuritis & 2 & 2 & $3.3 \%$ & 1 & $1.4 \%$ & 0.744 & 0.4593 \\
\hline schizophrenia & 2 & 2 & $3.3 \%$ & 1 & $1.4 \%$ & 0.744 & 0.4593 \\
\hline viral diseases & 2 & 2 & $3.3 \%$ & 2 & $2.7 \%$ & 0.183 & 0.8572 \\
\hline sepsis & 2 & 1 & $1.6 \%$ & 2 & $2.7 \%$ & 0.429 & 0.6672 \\
\hline all diseases (bioresonance therapy) & 2 & 1 & $1.6 \%$ & 2 & $2.7 \%$ & 0.429 & 0.6672 \\
\hline chronic obstructive pulmonary disease & 2 & 1 & $1.6 \%$ & 2 & $2.7 \%$ & 0.429 & 0.6672 \\
\hline attention deficit hyperactivity disorder & 2 & 0 & $0.0 \%$ & 2 & $2.7 \%$ & & \\
\hline stupor & 1 & 1 & $1.6 \%$ & 0 & $0.0 \%$ & 1.098 & 0.2713 \\
\hline anorexia & 1 & 0 & $0.0 \%$ & 1 & $1.4 \%$ & 0.744 & 0.4593 \\
\hline bulimia & 1 & 0 & $0.0 \%$ & 1 & $1.4 \%$ & 0.744 & 0.4593 \\
\hline blindness & 1 & 0 & $0.0 \%$ & 1 & $1.4 \%$ & 0.744 & 0.4593 \\
\hline fungal sepsis & 1 & 1 & $1.6 \%$ & 1 & $1.4 \%$ & 0.128 & 0.8966 \\
\hline infectious myocarditis & 1 & 1 & $1.6 \%$ & 1 & $1.4 \%$ & 0.128 & 0.8966 \\
\hline tooth decay & 1 & 1 & $1.6 \%$ & 1 & $1.4 \%$ & 0.128 & 0.8966 \\
\hline hair loss & 1 & 1 & $1.6 \%$ & 1 & $1.4 \%$ & 0.128 & 0.8966 \\
\hline shingles & 1 & 1 & $1.6 \%$ & 0 & $0.0 \%$ & 1.098 & 0.2713 \\
\hline seasickness & 1 & 1 & $1.6 \%$ & 0 & $0.0 \%$ & 1.098 & 0.2713 \\
\hline tetanus & 1 & 1 & $1.6 \%$ & 0 & $0.0 \%$ & 1.098 & 0.2713 \\
\hline retinopathy & 1 & 1 & $1.6 \%$ & 1 & $1.4 \%$ & 0.128 & 0.8966 \\
\hline acidosis & 1 & 1 & $1.6 \%$ & 1 & $1.4 \%$ & 0.128 & 0.8966 \\
\hline post-infection paralysis & 1 & 1 & $1.6 \%$ & 0 & $0.0 \%$ & 1.098 & 0.2713 \\
\hline
\end{tabular}


Supplementary table XII. cont. Frequency of drug-based and non-drug based methods in the treatment of non-cancer diseases

\begin{tabular}{|c|c|c|c|c|c|c|c|}
\hline & \multicolumn{3}{|c|}{$\begin{array}{l}\text { Drug-based } \\
\qquad(n=61)\end{array}$} & \multicolumn{2}{|c|}{$\begin{array}{l}\text { Non-drug based } \\
\qquad(n=73)\end{array}$} & \multicolumn{2}{|c|}{ z-test } \\
\hline & $\mathrm{n}$ & $\mathrm{n}$ & $\%$ & $n$ & $\%$ & statistic & $p$ \\
\hline absorption disorders & 1 & 1 & $1.6 \%$ & 1 & $1.4 \%$ & 0.128 & 0.8966 \\
\hline Huntington's disease & 1 & 1 & $1.6 \%$ & 1 & $1.4 \%$ & 0.128 & 0.8966 \\
\hline age-related macular degeneration & 1 & 1 & $1.6 \%$ & 1 & $1.4 \%$ & 0.128 & 0.8966 \\
\hline hypercholesterolemia & 1 & 1 & $1.6 \%$ & 1 & $1.4 \%$ & 0.128 & 0.8966 \\
\hline polycystic ovary syndrome & 1 & 1 & $1.6 \%$ & 1 & $1.4 \%$ & 0.128 & 0.8966 \\
\hline Down's syndrome & 1 & 0 & $0.0 \%$ & 1 & $1.4 \%$ & 0.744 & 0.4593 \\
\hline
\end{tabular}

